\title{
The influence of nurse education and training on communication, emotional intelligence, and empathy*
}

\author{
Impacto de la formación educativa de los enfermeros sobre la \\ comunicación, la inteligencia emocional y la empatía \\ Impacto da formação educacional dos enfermeiros sobre a \\ comunicação, a inteligência emocional e a empatia
}

How to cite this article:

Prado-Gasco VJ, Giménez-Espert MC, Valero-Moreno S. The influence of nurse education and training on communication, emotional intelligence, and empathy. Rev Esc Enferm USP. 2019;53:e03465. DOI: http://dx.doi.org/10.1590/S1980-220X2018015903465

\section{Vicente Javier Prado-Gascó ${ }^{1}$ \\ María del Carmen Giménez-Espert ${ }^{2}$ Selene Valero-Moreno ${ }^{3}$}

* Extracted from the thesis: "Actitudes hacia la comunicación, inteligencia emocional y empatía en enfermería”, Universidad de Valencia, 2016.

1 Universidad de Valencia, Facultad de Psicología, Departamento de Psicología Social, Valencia, Spain

2 Universidad de Valencia, Facultad de Enfermería y Podología, Departamento de Enfermería, Valencia, Spain.

3 Universidad de Valencia, Facultad de Psicología, Departamento de Personalidad, Evaluación y Tratamientos Psicológicos, Valencia, Spain.

\begin{abstract}
Objective: To determine the influence of nurse education and training on attitudes towards communication, emotional intelligence, and empathy. Method: A crosssectional study was conducted using three separate instruments to measure attitudes towards communication, empathy, and emotional intelligence, and two questions to determine the academic qualifications of the study participants. The effect of the variables was tested using one-way ANOVA, Pearson correlations, and hierarchical multiple linear regression. Results: The study sample comprised 438 nurses from hospitals in Valencia, Spain. Differences in subscale scores of the instruments according to degree level and specialized training were observed, showing that nurses with only a degree and less specialized training had lower capacity for empathy and emotional intelligence. The strongest correlations were found between the factors of the communication dimensions. Multiple linear regression showed that perspective taking and emotional clarity had the greatest predictive power. Conclusion: Degree level and specialized training were shown to influence the study variables and it is therefore necessary to prioritize education and training programs that promote the development of these skills to ensure improved service quality.
\end{abstract}

\section{DESCRIPTORS}

Education, Nursing; Health Communication; Emotional Intelligence; Empathy; NursePatient Relations. 


\section{INTRODUCTION}

The ability of nurses to understand patients and their attitude towards communication are key to providing quality healthcare ${ }^{(1)}$. Accurate empathic understanding of the patient and effective emotional management skills are essential for achieving higher levels of patient well-being and comfort ${ }^{(2)}$. Effective nurse communication is a precondition for effective care and improved patient outcomes ${ }^{(3)}$. It has also been shown to enhance treatment adherence and effectiveness in primary care settings ${ }^{(4)}$, relieve illness-related anxiety and depression $^{(5)}$, enhance illness control and convey realistic expectations to patients about their disease, improve disease course, contribute to patient safety and promote self-care and patient participation ${ }^{(6)}$, and prevent malpractice denunciations and lawsuits ${ }^{(7)}$. Nurse communication can be influenced by knowledge and attitudes ${ }^{(8)}$, emotional intelligence (EI), and empathy ${ }^{(9)}$. These factors can act as barriers to or facilitators of effective nurse-patient communication ${ }^{(10)}$.In general, studies have shown that nurses who lack EI and empathy also lack the ability to communicate effectively with patients and their team ${ }^{(11-12)}$, leading to a waste of resources and an increase in long-term direct and indirect healthcare costs. There are many possible definitions of emotional intelligence. For the purposes of this study, we use a definition widely adopted by professionals and academics ${ }^{(13)}$.

Despite the importance of these aspects of healthcare quality and effectiveness, research addressing the relationships between attitudes towards communication, EI and empathy remain scarce ${ }^{(14-15)}$.

EI and empathy can be influenced by both sociodemographic $^{(16)}$ and personal variables ${ }^{(13)}$. However, given that many of these traits can be developed through education and training, it seems likely that the acquisition of communication, emotional intelligence, and empathy skills among nurses is influenced by degree level and specialized training in patient care. In this respect, although some studies have shown that attitudes towards communication, empathy and EI are not associated with degree level ${ }^{(17)}$, others have shown that professionals with social science degrees obtained higher emotional intelligence and empathy scores and showed higher levels of emotional self-regulation compared to those with more technical qualifications ${ }^{(18)}$.

Despite the importance of formal education in developing these skills, we were unable to find studies analyzing the influence of degree level and specialized training on the abovementioned constructs ${ }^{(18)}$ and their interrelations. This study therefore examines the influence of degree level and number of specialized training courses on nurses' attitudes towards communication, empathy, and EI and the relationships between these variables.

\section{METHOD}

\section{Study Design}

A cross-sectional quantitative study was conducted using a single-stage sampling design.

\section{Population}

The study sample comprised 438 direct care nurses from seven public hospitals in Valencia.

\section{VARIABLES AND INSTRUMENTS}

The nurses' attitudes towards communication (ACO) were assessed using the ACO scale ${ }^{(14)}$. This 25 -item questionnaire measures ACO across three dimensions: affective, cognitive, and behavioral. This instrument has been shown to have adequate psychometric properties ${ }^{(19)}$.

Empathy was measured using the Jefferson Scale of Empathy for Nursing Students (JSE). Adapted and translated from the original version (Jefferson Scale of Physician Empathy) ${ }^{(20)}$, this 19-item scale measures empathy across three dimensions: perspective taking, compassionate care, and standing in the patient's shoes. Because the items in the subscales are negatively worded and thus reverse scored, higher subscale scores indicate lower capacity for empathy. The JSE has been shown to have adequate psychometric properties ${ }^{(19)}$.

EI was measured using a version of the Trait MetaMood Scale (TMMS24) adapted for use with Spanish nurses by Fernández-Berrocal ${ }^{(21)}$. The 24 -item scale assesses EI across three dimensions (emotional clarity, attention and repair) based on the model proposed by Meyer and Salovey, where EI refers to the ability to manage and distinguish between feelings and emotions, and use this knowledge to direct one's own thoughts and actions. Higher scores indicate higher capacity for EI. The TMMS24 has been shown to have adequate psychometric properties for use with nurses ${ }^{(22)}$.

\section{DATA ANALYSIS AND PROCESSING}

One-way ANOVA was used to examine differences in average subscale scores of the above mentioned instruments obtained by the nurses grouped according to degree level and number of specialized training courses. Pearson correlation coefficients were then calculated to measure the effect of the number of specialized training courses on ACO, empathy, and $\mathrm{EI}$ and the relationship between variables according to degree level. Finally, hierarchical multiple linear regression was conducted to test the relationship between variables according to degree level. The assumption of normality was met for all tests.

\section{ETHICAL ASPECTS}

This study was approved by the Research Ethics Committee of the Universidad de Valencia (application number H1432032268924) and the Clinical Research Ethics Committees of the participating hospitals. All participants signed an informed consent form.

\section{RESULTS}

\section{SOCIODEMOGRAPHIC CHARACTERISTICS OF THE PARTICIPANTS}

The average age of the participants was 44.13 years $(\mathrm{SD}=$ 11.58 , range 22 to 64 years). Over three-quarters of the sample (313 or $75.6 \%$ ) were women and $24.4 \%$ (101) were men. With respect to degree level, 79.7\% (295) of participants held a nursing degree, $17.8 \%$ (66) had a master's, and $2.4 \%$ (9) a doctorate. With regard to specialized training related to communication, empathy, and emotional intelligence, the 
majority of the nurses (50.1\% or 202 participants) had not received any training, 38\% (153) had undertaken one course, and $11.9 \%$ (48) had received adequate training.

\section{DifFerenCES IN SUBSCALE SCORES OF THE ACO SCALE, JSE, AND TMMS ACCORDING TO DEGREE LEVEL}

Statistically significant differences $(\mathrm{p} \leq 0.05)$ were observed in the compassionate care of JSE and emotional clarity of
TMMS $\left(\mathrm{F}=3.52 ; p=0.03 ; \eta^{2}=0.05\right.$ and $\mathrm{F}=3.54 ; p=0.03$; $\eta^{2}=0.08$, respectively). Participants with only a degree in nursing $(\mathrm{M}=1.89 ; \mathrm{SD}=0.87)$ obtained a slightly higher score than those with a doctorate $(\mathrm{M}=1.28 ; \mathrm{SD}=0.49)$ in the reverse scored compassionate care dimension, showing that the former had lower capacity for empathy, and a slightly lower score $(\mathrm{M}=3.80 ; \mathrm{SD}=0.69)$ than those with a master's in the emotional clarity dimension $(\mathrm{M}=4.01 ; \mathrm{SD}=0.64)$ (Table 1$)$.

Table 1 - Average subscale scores of the ACO scale, JSE, and TSMM24 of groups according to degree level - Valencia, 2016.

\begin{tabular}{|c|c|c|c|c|c|c|c|}
\hline & Degree level & Degree $M(S D)$ & Master's M(SD) & Doctorate $\mathrm{M}(\mathrm{SD})$ & $\mathbf{F}$ & $p$ & $\eta^{2}$ \\
\hline \multirow{3}{*}{ JSE } & Perspective taking & $4.54(0.54)$ & $4.54(0.63)$ & $4.38(0.47)$ & 0.28 & 0.76 & 0.06 \\
\hline & Compassionate care & $\begin{array}{c}1.89 \\
(0.87)\end{array}$ & $\begin{array}{c}1.69 \\
(0.83)\end{array}$ & $\begin{array}{c}1.28 \\
(0.49)\end{array}$ & 3.52 & $0.03 *$ & 0.05 \\
\hline & Standing in the patient's shoes & $2.01(1.03)$ & $2.11(1.07)$ & $1.28(0.49)$ & 0.80 & 0.45 & 0.03 \\
\hline \multirow{3}{*}{ TSMM24 } & Emotional attention & $3.57(0.76)$ & $3.68(0.80)$ & $3.69(0.79)$ & 0.62 & 0.54 & 0.05 \\
\hline & Emotional clarity & $\begin{array}{c}3.80 \\
(0.69)\end{array}$ & $\begin{array}{c}4.01 \\
(0.64)\end{array}$ & $\begin{array}{c}4.17 \\
(0.50)\end{array}$ & 3.54 & $0.03 *$ & 0.08 \\
\hline & Emotional repair & $3.83(0.73)$ & $3.86(0.83)$ & $4.18(0.50)$ & 0.04 & 0.96 & 0.04 \\
\hline \multirow[b]{2}{*}{$\mathrm{ACO}$} & Affective & $1.58(0.89)$ & $1.55(0.77)$ & $1.17(0.30)$ & 0.88 & 0.42 & 0.08 \\
\hline & Behavioral & $4.23(0.80)$ & $4.33(0.76)$ & $4.63(0.41)$ & 1.27 & 0.28 & 0.10 \\
\hline
\end{tabular}

Notes: $\mathrm{M}=$ mean; $\mathrm{SD}=$ standard deviation; $\mathrm{F}=\mathrm{f}$-test in one-way ANOVA; $\mathrm{p}=$ significance level; $\eta^{2}=$ eta squared; ${ }^{*} p \leq 0.05$; ** not calculated because no difference was observed between the groups.

\section{DifFerences in SUBSCALE SCORES OF THE ACO SCALE, JSE, AND TMMS ACCORDING TO SPECIALIZED TRAINING}

A statistically significant difference $(\mathrm{p} \leq 0.05)$ was found in the standing in the patient's shoes subscale $(\mathrm{F}=3.02 ; p=0.05$; $\left.\eta^{2}=0.01\right)$ in JSE. Nurses who had received little specialized training $(\mathrm{M}=2.14 ; \mathrm{SD}=1.03)$ obtained a slightly higher score than those who had received adequate specialized training $(\mathrm{M}=1.74 ; \mathrm{SD}=0.95)$ in this reverse scored dimension (Table 2), indicating that the nurses with less training would show less capacity for empathy. At this point, it seems necessary to remember that the items of this dimension are asked in the opposite direction, in such a way that high scores in this dimension imply a predisposition not to think like the patient.

Table 2 - Average subscale scores of the ACO scale, JSE, and TSMM24 of groups according to specialized training - Valencia, 2016.

\begin{tabular}{|c|c|c|c|c|c|c|c|}
\hline & Specialized training & No course $M(S D)$ & Little training $M(S D)$ & Adequate training $M(S D)$ & $\mathbf{F}$ & $p$ & $\eta^{2}$ \\
\hline & Perspective taking & $4.47(0.65)$ & $4.53(0.48)$ & $4.69(0.44)$ & 2.59 & 0.08 & 0.06 \\
\hline \multirow[t]{3}{*}{ JSE } & Compassionate care & $1.82(0.81)$ & $1.91(0.93)$ & $1.78(0.97)$ & 0.59 & 0.56 & 0.04 \\
\hline & Standing in the patient's shoes & $1.96(1.02)$ & $2.14(1.03)$ & $1.74(0.95)$ & 3.02 & $0.05^{*}$ & 0.01 \\
\hline & Emotional attention & $3.56(0.82)$ & $3.54(0.72)$ & $3.79(0.68)$ & 1.87 & 0.16 & 0.04 \\
\hline \multirow[t]{3}{*}{ TSMM24 } & Emotional clarity & $3.76(0.73)$ & $3.86(0.68)$ & $3.98(0.54)$ & 2.14 & 0.12 & 0.09 \\
\hline & Emotional repair & $3.75(0.77)$ & $3.87(0.78)$ & $3.97(0.62)$ & 2.03 & 0.13 & 0.05 \\
\hline & Affective & $1.61(0.88)$ & $1.59(0.89)$ & $1.42(0.81)$ & 0.84 & 0.43 & 0.12 \\
\hline \multirow[t]{2}{*}{$\mathrm{ACO}$} & Behavioral & $4.15(0.92)$ & $4.22(0.69)$ & $4.45(0.60)$ & 2.59 & 0.08 & 0.09 \\
\hline & Cognitive & $4.50(0.83)$ & $4.45(0.88)$ & $4.70(0.57)$ & 1.65 & 0.19 & 0.04 \\
\hline
\end{tabular}

Notes: $\mathrm{M}=$ mean; $\mathrm{SD}=$ standard deviation; $\mathrm{F}=\mathrm{f}$-test in one-way ANOVA; $\mathrm{p}=$ significance level; $\eta^{2}=$ eta squared; ${ }^{*} p \leq 0.05 ;{ }^{* *}$ not calculated because no difference was observed between the groups. 
CoRrelations between THE SUBSCALE SCORES OF THE ACO SCALE, JSE AND TMMS24 ACCORDING TO DEGREE LEVEL

The correlations between the subscale scores of the abovementioned instruments and number of specialized training courses were examined according to degree level. In this respect, given the small number of nurses with higher degrees, those with master's or doctorate degrees were grouped together for analysis purposes. The results of this analysis showed statistically significant correlations across the majority of the dimensions of the three instruments in both groups. For both groups, the highest correlations were found for the separate dimensions of each scale. In this respect, high positive correlations were observed between factor pairs of the ACO scale among both nurses with only a degree ( $r=-0.63$ between the affective and behavioral dimensions; $r=-0.76$ between the affective and cognitive dimensions; and $\mathrm{r}=0.77$ between the cognitive and behavioral dimensions) and those with a masters or doctorate ( $r=-0.69$ between the affective and behavioral dimensions; $r=-0.70$ between the affective and cognitive dimensions; and $r=0.70$ between the cognitive and behavioral dimensions). In contrast, no statistically significant correlation was found between the emotional attention dimension of the TMMS24 and the dimensions of the ACO scale among both groups: nurses with only a degree - affective dimension $(r=-0.12 ; p \geq 0.05)$, behavioral dimension $(r=0.10 ; p \geq 0.05)$, and cognitive dimension ( $r=0.12 ; \mathrm{p} \geq 0.05)$; nurses with a masters or doctorate - affective dimension $(r=-0.05 ; p \geq 0.05)$, behavioral dimension ( $r=0.10 ; p \geq 0.05)$, and cognitive dimension $(r=0.17 \mathrm{p} \geq 0.05)$. However, a low positive correlation was found between emotional attention and the perspective taking dimension of the JSE among nurses with only a degree $(r=0.25 ; p \leq 0.05)$, while a moderate negative correlation was found with the standing in the patient's shoes dimension of the JSE among nurses with a master's or doctorate $(r=-$ $0.31 ; \mathrm{p} \leq 0.05)$.

No statistically significant relationship ( $\mathrm{p} \geq 0.05)$ was found between number of courses undertaken and the subscale scores of the ACO scale, JSE, and TMMS24 among both groups (Table 3 ).

Table 3 - Pearson correlation matrix for the subscale scores of the ACO scale, JSE, and TMSS24 according to degree level - Valencia, 2016.

\begin{tabular}{|c|c|c|c|c|c|c|c|c|c|c|}
\hline Degree level & & $\begin{array}{c}\text { Affective } \\
\text { (ACO scale) }\end{array}$ & $\begin{array}{c}\text { Behavioral } \\
\text { (ACO scale) }\end{array}$ & $\begin{array}{l}\text { Cognitive } \\
\text { (ACO scale) }\end{array}$ & $\begin{array}{l}\text { PT } \\
\text { (JSE) }\end{array}$ & $\begin{array}{l}\text { CC } \\
\text { (JSE) }\end{array}$ & $\begin{array}{c}\text { SS } \\
\text { (JSE) }\end{array}$ & $\begin{array}{c}\text { EA } \\
\text { (TMMS24) }\end{array}$ & $\begin{array}{c}\text { EC } \\
\text { (TMMS24) } \\
\end{array}$ & $\begin{array}{c}\text { ER } \\
\text { (TMMS24) }\end{array}$ \\
\hline \multirow{9}{*}{ DEGREE } & 2 & $-0.63^{* *}$ & & & & & & & & \\
\hline & 3 & $-0.76^{* *}$ & $0.77^{* *}$ & & & & & & & \\
\hline & 4 & $-0.31^{* *}$ & 0.47 & $0.50^{* *}$ & & & & & & \\
\hline & 5 & $0.27^{* *}$ & $-0.17^{* *}$ & $-0.29^{*}$ & $-0.41^{* *}$ & & & & & \\
\hline & 6 & $0.21^{* *}$ & $-0.21^{* *}$ & $-0.22 * *$ & $-0.26^{* *}$ & $0.43^{* *}$ & & & & \\
\hline & 7 & -0.03 & 0.07 & 0.08 & $0.25^{* *}$ & -0.10 & -0.03 & & & \\
\hline & 8 & $-0.17^{* *}$ & $0.27^{* *}$ & $0.21^{* *}$ & $0.34^{* *}$ & $-0.17^{* *}$ & $-0.17^{* *}$ & $0.38^{* *}$ & & \\
\hline & 9 & -0.09 & $0.29^{* *}$ & $0.18^{* *}$ & $0.37^{* *}$ & -0.12 & -0.12 & $0.16^{* *}$ & $0.53^{* *}$ & \\
\hline & 10 & -0.01 & 0.08 & -0.02 & 0.08 & 0.10 & 0.03 & 0.04 & 0.04 & 0.09 \\
\hline \multirow{9}{*}{$\begin{array}{l}\text { MASTER'S AND } \\
\text { DOCTORATE }\end{array}$} & 2 & $-0.69^{* *}$ & & & & & & & & \\
\hline & 3 & $-0.70^{* *}$ & $0.70^{* *}$ & & & & & & & \\
\hline & 4 & $-0.50^{* *}$ & $0.51 * *$ & $0.50^{* *}$ & & & & & & \\
\hline & 5 & $0.28^{*}$ & -0.20 & $-0.29 *$ & $-0.61 * *$ & & & & & \\
\hline & 6 & 0.12 & $-0.26^{*}$ & -0.03 & $-0.33^{* *}$ & 0.22 & & & & \\
\hline & 7 & -0.21 & 0.08 & -0.04 & 0.22 & -0.20 & $-0.31^{*}$ & & & \\
\hline & 8 & $-0.54^{* *}$ & $0.40^{* *}$ & $0.38^{* *}$ & $0.32 *$ & -0.15 & -0.16 & 0.19 & & \\
\hline & 9 & -0.25 & $0.38^{* *}$ & 0.17 & $0.28^{*}$ & $-0.27^{*}$ & $-0.36^{* *}$ & $0.40^{* *}$ & $0.36^{* *}$ & \\
\hline & 10 & -0.17 & 0.16 & 0.23 & 0.22 & 0.19 & -0.20 & 0.01 & 0.20 & 0.06 \\
\hline
\end{tabular}

Notes: $\mathrm{PT}=$ perspective taking; $\mathrm{CC}=$ compassionate care; $\mathrm{SS}=$ standing in the patient's shoes; $\mathrm{EA}=$ emotional attention; $\mathrm{EC}=\mathrm{emotional}$ clarity; $\mathrm{ER}=$ emotional repair; $2=$ behavioral (ACO scale); $3=\operatorname{cog}$ nitive (ACO scale); 4=PT; $5=\mathrm{CC} ; 6=\mathrm{SS} ; 7=\mathrm{EA} ; 8=\mathrm{EC} ; 9=\mathrm{ER} ; 10=\mathrm{No}^{\mathbf{o}}$ of specialized training courses undertaken; * statistically significant correlation $p \leq 0.05 ;{ }^{* *}$ statistically significant correlation $p \leq 0.01$

\section{HIERARCHICAL MULTIPLE LINEAR REGRESSION ACCORDING TO DEGREE LEVEL}

Hierarchical regression was performed to determine the predictive power of the variables according to degree level. The criterion variables were the dimensions of the ACO scale and the predictor variables were number of specialized training courses, the dimensions of the JSE, and the dimensions of the TMMS24, included in the first, second, and third steps, respectively. The results of the first step showed that the variable number of courses did not significantly predict any of the dimensions of the ACO scale in either group. In the second step, the dimensions of the JSE explained $12 \%$ of the variance of the affective dimension of the ACO scale 
$\left(\Delta \mathrm{R}^{2}=.12, p \leq .001\right), 20 \%$ of the cognitive dimension $\left(\Delta \mathrm{R}^{2}=.20\right.$, $p \leq .000)$, and $23 \%$ of the behavioral dimension $\left(\Delta \mathrm{R}^{2}=.23\right.$, $p \leq .000$ ) in the group with only a degree. In the group with a master's or doctorate the dimensions of JSE predicted $20 \%$ of the variance of affective dimension $\left(\Delta \mathrm{R}^{2}=.20, p=0.01\right)$, $26 \%$ of the cognitive dimension $\left(\Delta \mathrm{R}^{2}=.26, p \leq .001\right)$, and $26 \%$ of the behavioral dimension $\left(\Delta \mathrm{R}^{2}=.26, p \leq .000\right)$. After including the dimensions of the TMMS24 in the third step, the proportion of variance explained increased significantly in the behavioral dimension $\left(24 \% ; \Delta \mathrm{R}^{2}=.03, p \leq .001\right)$ and noincreased in the affective and cognitive dimensions (11\%; $\Delta \mathrm{R}^{2}=.01, p \leq .001$ and $19 \% ; \Delta \mathrm{R}^{2}=.00, p \leq .001$, respectively) in the group with only a degree, while in the group with a master's or doctorate the proportion of variance explained increased significantly across all dimensions $\left(37 \% ; \Delta \mathrm{R}^{2}=.17\right.$, $p \leq .001$ for affective; $31 \% \Delta \mathrm{R}^{2}=.05, p \leq .001$ for behavioral; and $33 \% ; \Delta \mathrm{R}^{2}=.07, p \leq .001$ for cognitive).

With respect to the group with only a degree, the results of the third step showed a statistically significant negative correlation between the perspective taking dimension and the affective dimension $(\beta=-0.27 ; p \leq .000)$ and a positive correlation for the cognitive and behavioral dimensions $(\beta=0.42$; $p \leq .000$ and $\beta=0.45 ; p \leq .000$, respectively). Furthermore, a statistically significant negative correlation was observed between the emotional clarity dimension and the affective dimension $(\beta=-0.16 ; p=0.04)$. In the group with a master's or doctorate, a statistically significant positive correlation was found between the perspective taking dimension and behavioral and cognitive dimensions $(\beta=0.46 ; p=0.01$ and $\beta=0.45 ; p=0.01$, respectively) and a negative correlation was observed for the affective dimension $(\beta=-0.40 ; p=0.01)$. Furthermore, a statistically significant negative correlation was found between the emotional clarity and affective dimensions $(\beta=-0.43 ; p \leq .000)$ and a positive correlation was observed for the cognitive dimension $(\beta=0.31 ; p=0.01)$. The results therefore show that the same variables (perspective taking and emotional clarity) predicted the factors of the ACO scale in both groups.
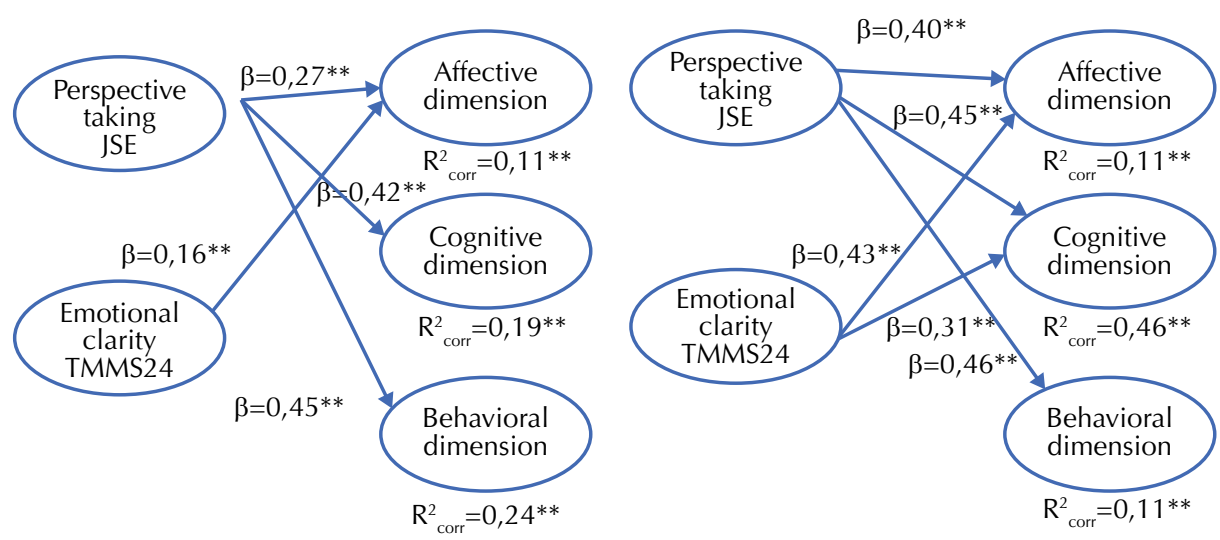

Notes. *significance level $p \leq 0.05$; **ignificance level $p \leq 0.01$.

Figure 1 - Model of the relationships between study variables according to degree level - Valencia, 2016

\section{DISCUSSION}

Communication, IE, and empathy are critical components of quality nursing care ${ }^{(3)}$. Likewise, the ability of nurses to communicate effectively can significantly improve patient outcomes by: enhancing treatment adherence and effectiveness ${ }^{(4)}$, relieving illness-related anxiety and depression ${ }^{(5)}$, promoting patient self-care ${ }^{(6)}$, and reducing health costs by preventing malpractice denunciations and increasing the nursing team effectiveness ${ }^{(7-8)}$.

According to the literature, these traits are influenced by situational or extrinsic factors, which are more difficult to control, and dispositional or intrinsic factors, such as personal skills ${ }^{(14-15)}$, which may be moderated by variables such as sex and age ${ }^{(14)}$.

Thus, as the literature suggests, these traits can be learned and therefore training plays a key role in promoting effective communication with patients, empathy and EI. In this respect, degree level and specialized training courses designed to develop the skills required for effective patient care are of utmost importance. Despite this, studies examining the effect of these variables on communication with patients, empathy, and EI do not exist ${ }^{(17-18)}$.

The aim of this study was therefore to determine the influence of aspects of education and training (degree level and number of specialized training courses) on nurses' attitudes towards communication, EI, and empathy.

Our findings showed statistically significant differences in compassionate care and emotional clarity according to degree level. Nurses with only a degree obtained inferior scores for compassionate care dimension than those with a doctorate and lower scores for emotional clarity than those with a master's, which is in line with the results of previous studies ${ }^{(17)}$. No differences were observed across the rest of the variables. With respect to number of specialized training courses, nurses with a low number of courses obtained higher scores in the reverse scored standing in the patient's shoes dimension, thus 
showing lower capacity for empathy. These results suggest that specialized training courses help nurses to manage their emotions and interact more effectively with patients, which is crucial given that excessive emotional involvement with patients can compromise the management of complicated situations in health settings.

In both groups (those with only a degree and those with a master's or doctorate), a statistically significant correlation was found for the majority of the dimensions, except between the ACO scale and the emotional attention dimension of the TMMS24. Furthermore, no significant association was observed between number of specialized training courses and attitude towards communication. However, a significant correlation was found between this factor and IE and empathy, as shown by previous studies $^{(17-18)}$. Furthermore, a relationship was observed between the dimensions of the JSE scale and the affective dimension of the ACO scale (regardless of the degree level or specific courses received), except for the perspective taking dimension, which showed a correlation with the cognitive and behavioral dimensions ${ }^{(16)}$. Similar results were found for the relationship between EI and attitudes towards communication, as shown by other studies ${ }^{(16)}$.

Finally, multiple linear regression showed that, in general, regardless of the degree, two variables had the greatest predictive power across all dimensions of the ACO scale. With respect to empathy, the variable that best predicted attitude towards communication was perspective taking, showing a particularly high predictive power in the cognitive and behavioral dimensions, while with regard to EI, the emotional clarity dimension had the highest predictive power for the affective dimension, demonstrating particularly high power in the group with a master's or doctorate degree. In this respect, perspective taking is related to the cognitive dimension of empathy and emotional clarity and to the ability to understand feelings. Thus, the better performance in the cognitive dimension of empathy and IE, the more likely nurses are to have a more favorable attitude towards communication and better understand their patients ${ }^{(12,14)}$. To achieve effective communication, "the nurse has to ensure an emotional, personal, and interpersonal climate where it is possible to use communication strategies directed at understanding and managing the experiences and feelings of the patient and his/her family and his/her own emotional reactions" ${ }^{(17)}$. It therefore seems that degree level and specialized training influenced the studied variables: attitude towards communication, empathy and EI. In this respect, our findings show that the higher the degree level or greater the number of specialized training courses, the higher the scores in these variables or, in other words, the better equipped these professionals are to relate to their patients.

Despite these contributions, this study has certain limitations related to sampling and data collection. First, the nonprobability sample is not necessarily representative of all nurses. In this respect, the proportion of nurses with only a degree was significantly greater than those with a master's or doctorate. As a result, it is not possible to generalize the findings. Future studies should use probability sampling and broaden the sample to include other contexts and cultures. However, this is a common limitation in studies in this area and, given the large sample size, which was greater than other studies, the findings provide an important first insight into this phenomenon.

A second limitation was the use of self-report questionnaires. Although one of the most widely used assessment strategies, these instruments can lead to social desirability bias. In this respect, it is recommended that future studies use more objective, external measures. Measures will be taken to address these limitations in future studies. Despite these limitations, this study helps bridge a gap in the literature in relation to the influence of education and training in communication, EI, and empathy, providing a significant insight into this area. Its findings are therefore of particular interest given that the final outcome of effective nurse-patient communication is a reduction in human error ${ }^{(19)}$ and direct and indirect health $\operatorname{costs}^{(4)}$ and improved disease adaptation ${ }^{(6-7)}$. The findings of this study suggest that these components of nursing care should occupy a more prominent position in the curriculums of degrees and training programs.

\section{CONCLUSION}

This study shows how education and training (degree level and specialized training courses) can influence attitude towards communication, EI, and empathy and the relationships between these variables. Our findings demonstrate the key role that adequate education and training and degree level play in the provision of quality nursing care and the importance of planning and evaluating nurse training programs that provide the communication, emotional intelligence, and empathy skills necessary to improve patient care and service effectiveness. Due consideration should be given to these variables not only because of their impact on patient satisfaction and service quality, but also due to the crucial importance of incorporating the development of these skills into nurse education and training from the beginning in order to produce adequately qualified nursing professionals. 
RESUMEN

Objetivo: Determinar el impacto de la formación académica del enfermero en sus actitudes hacia la comunicación, inteligencia emocional y empatía. Método: Diseño transversal, se utilizó un instrumento para medir actitudes hacia la comunicación, otro para empatía, y un último para inteligencia emocional y dos preguntas para analizar la formación de los participantes. Para comprobar el efecto de las variables estudiadas se realizaron ANOVA de un factor, correlaciones de Pearson y modelos de regresión lineal múltiple jerárquica. Resultados: La muestra de estudio fue de 438 enfermeras de hospitales de Valencia. Existen diferencias en las variables estudiadas en función de la titulación y formación específica recibida, observando menor capacidad empática e inteligencia emocional en los graduados y en los de menor formación específica. Las correlaciones más fuertes fueron entre los factores de las dimensiones de comunicación. La toma de perspectiva y claridad emocional fueron las principales variables predictoras en los modelos de regresión. Conclusión: La formación académica influye en las variables estudiadas, por todo ello parece necesario elaborar programas educativos que incidan en enseñar dichas habilidades, para asegurar una mejor calidad del servicio.

\section{DESCRIPTORES}

Educación en Enfermería; Comunicación en Salud; Inteligencia Emocional; Empatía; Relaciones Enfermero-Paciente.

\section{RESUMO}

Objetivo: Determinar o impacto da formação acadêmica do enfermeiro nas suas atitudes voltadas para a comunicação, a inteligência emocional e a empatia. Método: Elaboração transversal, na qual foi utilizado um instrumento para medir as atitudes voltadas para a comunicação, outro para a empatia e um último para a inteligência emocional e duas perguntas para analisar a formação dos participantes. Para comprovar o efeito das variáveis estudadas, foram realizadas ANOVA de um fator, correlações de Pearson e modelos de regressão linear múltipla hierárquica. Resultados: A amostra de estudo foi de 438 enfermeiras de hospitais de Valência. Existem diferenças nas variáveis estudadas em função da titulação e formação específica recebida, observando menor capacidade empática e inteligência emocional nos graduados e nos de menor formação específica. As correlações mais fortes foram entre os fatores das dimensões de comunicação. A tomada de perspectiva e clareza emocional foram as principais variáveis preditoras nos modelos de regressão. Conclusão: A formação acadêmica influi nas variáveis estudadas, portanto, parece necessário elaborar programas educacionais que incidam no ensino dessas habilidades para garantir uma melhor qualidade do serviço.

\section{DESCRITORES}

Educação em Enfermagem; Comunicação em Enfermagem; Inteligência Emocional; Empatia; Relações Enfermeiro-Paciente.

\section{REFERENCES}

1. Müggenburg MC, Riveros-Rosas A. Interacción enfermera-paciente y su repercusión en el cuidado hospitalario: Parte I. Enferm Univ. 2012;1(9):36-4. DOI: http://dx.doi.org/10.22201/eneo.23958421e.2012.1.33255

2. Eide H, Sibbern T, Johannessen T. Empathic accuracy of nurses' immediate responses to fibromyalgia patients' expressions of negative emotions: an evaluation using interaction analysis. J Adv Nurs. 2011;67(6):1242-53. DOI: https://doi.org/10.1111/j.1365-2648.2010.05579.x

3. Ghiyasvandian S, Zakerimoghadam M, Peyravi H. Nurse as a facilitator to professional communication: a qualitative study. Glob J Health Sci [Internet]. 2014;7(2):294-3. Available from: https://www.ncbi.nlm.nih.gov/pmc/articles/PMC4796404/

4. Van Os TW, van den Brink RHS, Tiemens BG, Jenner JA, van der Meer K, Ormel J. Communicative skills of general practitioners augment the effectiveness of guideline-based depression treatment. J Affect Disord. 2005;84(1):43-51. DOI: https://doi.org/10.1016/j.jad.2004.09.005

5. Thorne S, Oliffe JL, Stajduhar KI, Oglov V, Kim-Sing C, Hislop TG. Poor communication in cancer care: patient perspectives on what it is and what to do about it. Cancer Nurs. 2013;36(6):445-3. DOI: 10.1097/NCC.0b013e31827eeda4

6. Davies NJ, Kinman G, Thomas RJ, Bailey T. Information satisfaction in breast and prostate cancer patients: implications for quality of life. Psychooncology. 2008; 17(10):1048-52. DOI: https://doi.org/10.1002/pon.1305

7. Lefevre FV, Waters TM, Budetti PP. A survey of physician training programs in risk management and communication skills for malpractice prevention. J Law Med Ethics. 2000;28(3):258-6.

8. Sheldon LK, Barrett R, Ellington L. Difficult communication in nursing. J Nurs Scholarsh. 2006;38(2):141-7. DOI: https://doi.org/10.1111/ j.1547-5069.2006.00091.x

9. Mullan BA, Kothe EJ. Evaluating a nursing communication skills training course: The relationships between self-rated ability, satisfaction, and actual performance. J Nurs Educ Pract. 2010;10(6):374-8. DOI:http://dx.doi.org/10.1016/j.nepr.2010.05.007

10. McQueen ACH. Emotional intelligence in nursing work. J Adv Nurs. 2004;47(1):101-8. DOI: https://doi.org/10.1111/j.13652648.2004.03069.x

11. Kooker BM, Shoultz J, Codier EE. Identifying emotional intelligence in professional nursing practice. J Prof Nurs. 2007;23(1):30-6. DOI: https://doi.org/10.1016/j.profnurs.2006.12.004

12. Brunero S, Lamont S, Coates M. A review of empathy education in nursing. Nurs Inq. 2010;17(1):65-4. DOI: https://doi.org/10.1111/j.14401800.2009.00482.x

13. Mayer JD, Salovey P. What is emotional intelligence? In: P. Salovey P, Sluyter D, editors. Emotional development and emotional intelligence: implications for educators. New York: Basic Books; 1997. p. 3-31.

14. Agarwal R, Sands DZ, Schneider JD. Quantifying the economic impact of communication inefficiencies in US hospitals. J Healthc Manag. 2010;55(4):265.

15. Giménez-Espert MC, Prado-Gascó VJ. The development and psychometric validation of an instrument to evaluate nurses' attitudes towards communication with the patient (ACO). Nurse Educ Today. 2018;64:27-32. DOI: https://doi.org/10.1016/j.nedt.2018.01.031

16. Giménez-Espert MC, Prado-Gascó VJ. The moderator effect of sex on attitude toward communication, emotional intelligence, and empathy in the nursing field. Rev Latino Am Enfermagem [Internet]. 2017;25:e2969. DOI: http://dx.doi.org/10.1590/1518-8345.2018.2969 
17. López-Fernández C. Inteligencia emocional y relaciones interpersonales en los estudiantes de enfermería. Educ Méd. 2015;16(19):83-2. DOI: https://doi.org/10.1016/j.edumed.2015.04.002

18. Fortes-Villatella M, Xavier O, Gemma F, Isabel DA, Soldevilla A. Inteligencia emocional y personalidad en las diferentes áreas de conocimiento de los estudiantes universitarios. Rev Electr Interuniv Form Profr [Internet]. 2013 [citado 2018 dez. 06];16(1):109-20. Disponible en: https://www.redalyc.org/pdf/2170/217028056010.pdf

19. Giménez-Espert MC, Prado-Gascó VJ. The role of empathy and emotional intelligence in nurses' communication attitudes using regression models and fuzzy-set qualitative comparative analysis models (fsQCA). J Clin Nurs. 2018;27:2661-72. DOI: https://doi.org/10.1111/ jocn. 14325

20. Ward J, Schaal M, Sullivan J, Bowen ME, Erdmann JB, Hojat M. Reliability and validity of the Jefferson Scale of Empathy in undergraduate nursing students. J Nur Meas. 2009;17(1):73-8.

21. Fernandez-Berrocal P, Extremera N, Ramos N. Validity and reliability of the Spanish modified version of the Trait Meta-Mood Scale. Psychol Rep. 2004;94(3):751-5. DOI: https://doi.org/10.2466/pr0.94.3.751-755

22. Giménez-Espert MC, Prado-Gascó VJ. Emotional intelligence in nurses: the Trait Meta-Mood Scale. Acta Paul Enferm. 2017;30(2):204-9. DOI: http://dx.doi.org/10.1590/1982-0194201700031 